\title{
Physical pathways for carbon transfers between the surface mixed layer and the ocean interior
}

\author{
M. Levy, ${ }^{1}$ L. Bopp, ${ }^{2}$ P. Karleskind, ${ }^{3}$ L. Resplandy, ${ }^{2}$ C. Ethe,,${ }^{1,2}$ and F. Pinsard ${ }^{1}$ \\ Received 27 February 2013; revised 6 September 2013; accepted 11 September 2013; published 2 October 2013.
}

[1] Although they are key components of the surface ocean carbon budget, physical processes inducing carbon fluxes across the mixed-layer base, i.e., subduction and obduction, have received much less attention than biological processes. Using a global model analysis of the preindustrial ocean, physical carbon fluxes are quantified and compared to the other carbon fluxes in and out of the surface mixed layer, i.e., air-sea $\mathrm{CO}_{2}$ gas exchange and sedimentation of biogenic material. Model-based carbon obduction and subduction are evaluated against independent data-based estimates to the extent that was possible. We find that climatological physical fluxes of dissolved inorganic carbon (DIC) are two orders of magnitude larger than the other carbon fluxes and vary over the globe at smaller spatial scale. At temperate latitudes, the subduction of DIC and to a much lesser extent $(<10 \%)$ the sinking of particles maintain $\mathrm{CO}_{2}$ undersaturation, whereas DIC is obducted back to the surface in the tropical band (75\%) and Southern Ocean (25\%). At the global scale, these two large counter-balancing fluxes of DIC amount to $+275.5 \mathrm{PgC} \mathrm{yr}^{-1}$ for the supply by obduction and $-264.5 \mathrm{PgC} \mathrm{yr}^{-1}$ for the removal by subduction which is $\sim 3$ to 5 times larger than previous estimates.

Moreover, we find that subduction of organic carbon (dissolved and particulate) represents $\sim 20 \%$ of the total export of organic carbon: at the global scale, we evaluate that of the $11 \mathrm{PgC} \mathrm{yr}-1$ of organic material lost from the surface every year, $2.1 \mathrm{PgC} \mathrm{yr}^{-1}$ is lost through subduction of organic carbon. Our results emphasize the strong sensitivity of the oceanic carbon cycle to changes in mixed-layer depth, ocean currents, and wind.

Citation: Levy, M., L. Bopp, P. Karleskind, L. Resplandy, C. Ethe, and F. Pinsard (2013), Physical pathways for carbon transfers between the surface mixed layer and the ocean interior, Global Biogeochem. Cycles, 27, 1001-1012, doi:10.1002/gbc.20092.

\section{Introduction}

[2] It is widely recognized that the ocean circulation exerts a significant control on the air-sea $\mathrm{CO}_{2}$ flux and that knowledge of the physical mechanisms responsible for carbon exchanges between the well-ventilated surface mixed layer and the ocean interior is key to understanding changes in carbon uptake by the ocean [i.e., Follows et al., 1996; Thomas et al., 2008; Ullman et al., 2009; Cao et al., 2009]. Nevertheless and perhaps surprisingly, the regional pathways and rate at which physical processes induce carbon fluxes across the base of the mixed layer have received much less attention than the biological pathways and remain largely unquantified [Ayers and Lozier, 2012].

[3] The physical transfer of carbon across the base of the mixed layer is a process known as carbon subduction

\footnotetext{
Additional supporting information may be found in the online version of this article.

${ }^{1}$ LOCEAN-IPSL, CNRS/IRD/UPMC/MNHN, Paris, France.

${ }^{2}$ LSCE-IPSL, CNRS/CEA/UVSQ, Saclay, France.

${ }^{3}$ ALTRAN-OUEST, Brest, France.

Corresponding author: M. Levy, LOCEAN-IPSL, UPMC, 4 Place Jussieu, 75252 Paris CEDEX 05, France. (marina@locean-ipsl.upmc.fr)

(C)2013. American Geophysical Union. All Rights Reserved. 0886-6236/13/10.1002/gbc. 20092
}

when carbon is transferred from the mixed layer to the ocean interior and as carbon obduction when carbon originating from the interior enters the mixed layer. At the global scale, the amount of carbon exchanged between the surface mixed layer and the ocean interior each year is uncertain; its estimate has varied by a factor of two between the third (TAR) [Prentice et al., 2001] and fourth (AR4) [Denman et al., 2007] Intergovernmental Panel on Climate Change Assessment Reports.

[4] A few regional studies have started to emphasize the important role of subduction in the sequestration of dissolved inorganic carbon (DIC) [Follows et al., 1996; Bates et al., 2002; Oschlies and Kähler, 2004; Karleskind et al., 2011b, 2011a; Iudicone et al., 2011; Ayers and Lozier, 2012] and of anthropogenic $\mathrm{CO}_{2}$ [Levine et al., 2011; Sallée et al., 2012]. In the North Pacific, based on observational data, Ayers and Lozier [2012] find that geostrophic circulation plays a role comparable to biological drawdown in maintaining the carbon sink of the region. In the North Atlantic, using a model, Oschlies and Kähler [2004] show that subduction of inorganic matter can account for up to half of the biotically mediated air-sea $\mathrm{CO}_{2}$ fluxes in specific subduction regions. In the Northeast Atlantic, based on a combined model/data analysis, Karleskind et al. [2011b] find that carbon subduction is nearly two orders of magnitude 


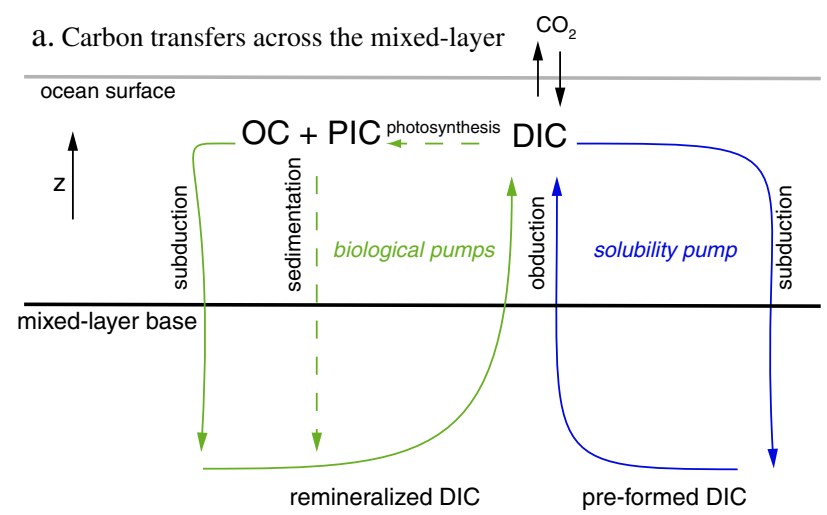

b. Processes contributing to physical transfers across the mixed-layer

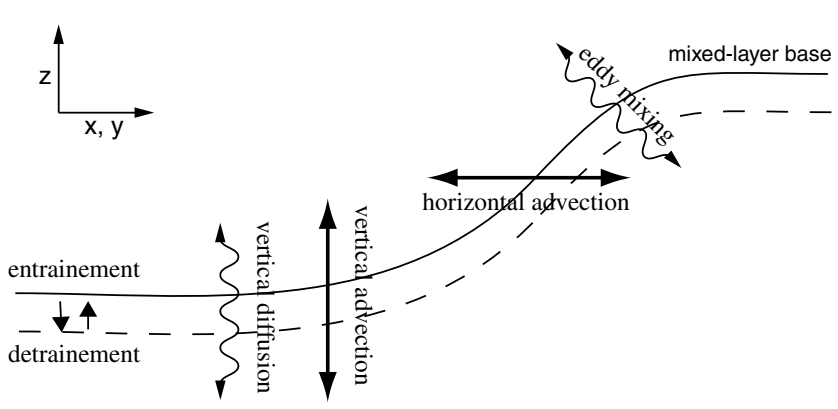

Figure 1. (a) A 1-D vertical scheme of carbon transfers across the mixed-layer base interface (DIC: dissolved inorganic carbon, OC: sum of dissolved and particulate organic carbon, PIC: particulate inorganic carbon). Physical transfers (subduction/obduction): plain lines; Biological transfer (sedimentation): dashed line. The solubility pump involves subduction of DIC and obduction of preformed DIC. The biological pump involves sedimentation and subduction of OC (soft tissue pump) and PIC (carbonate pump) and also involves obduction of remineralized DIC. (b) A 2-D cross section of the different processes involved in the physical transfer of carbon across the sloping mixed layer. The solid line is the seasonal Mixed-Layer Depth (MLD) and the dashed line is the wintertime MLD. The sum of these fluxes corresponds to net carbon subduction/obduction.

larger than the biological carbon export through sedimentation. Inversely, obduction has been identified as an important pathway for nitrate supply to the surface in the Gulf stream region [Williams et al., 2006; Palter and Lozier, 2008; Williams et al., 2011] as well as an important pathway for DIC rich deep waters to return to the surface in the Southern Ocean [LeQuere et al., 2007]. However, a complete global picture is still lacking.

[5] In this paper, our intention is to propose a revised mixed-layer carbon budget with emphasis on carbon subduction and obduction between the surface of the ocean and the ocean interior. To this end, we examine and quantify the physical processes responsible for carbon transfers by subduction and obduction and compare them to other forms of carbon transfers in and out of the ocean surface boundary layer (such as air-sea $\mathrm{CO}_{2}$ flux and biological carbon export through sedimentation), at the regional scale and at the global scale. This is achieved through a global sea-ice ocean-circulation model with embedded biogeochemistry set to simulate preindustrial carbon fluxes. To strengthen the results, model-based carbon obduction and subduction are evaluated against independent data-based estimates to the extent that was possible.

[6] The mixed-layer depth provides a natural reference level to evaluate the physical transfers because it sets the vertical limit of the material that is in direct contact with the atmosphere [Oschlies and Kähler, 2004]. In contrast to the biological transfers through sedimentation, which are directed out of the mixed layer, physical transfers operate both ways and their net effect is to deliver (mostly) DIC to the mixed layer and to subduct organic and inorganic carbon out of the mixed layer (Figure 1a). Fluxes involved in the physical transfer result from a combination of different physical mechanisms: seasonal entrainment/detrainment due to variations in mixed-layer depth, vertical diffusion at the mixed-layer base, horizontal advection across the sloping mixed-layer base, vertical advection, and mixing due to mesoscale eddies (Figure 1b). Here we also examine the large regional contrasts in the physical carbon transfers through these different mechanisms. This is a prerequisite to understand how carbon fluxes between the surface and the deep ocean have evolved in the past or are likely to evolve in the future, in response to changes in the ocean circulation, thermodynamics, and biology [Riebesell et al., 2009].

[7] The next paragraph presents the method to evaluate carbon transfers from the model and from data. Results are presented in section 3, starting with a regional description of the physical and biological transfers, examining the driving processes and main pathways and proposing a revised global mixed-layer carbon budget.

\section{Method}

\subsection{Carbon Transfer Diagnostics}

[8] The evolution of any ocean tracer C (comprising carbon) follows the transport equation:

$$
\partial_{t} \mathrm{C}=-w \partial_{z} \mathrm{C}-\boldsymbol{u} \cdot \nabla_{H} \mathrm{C}+\partial_{z}\left(k_{z} \partial_{z} \mathrm{C}\right)+E_{\mathrm{C}}+S_{\mathrm{C}}
$$

where $w, \boldsymbol{u}, k_{z}$ are the vertical velocity, horizontal velocity, and vertical diffusion coefficient, respectively. Eddy mixing $E_{\mathrm{C}}$ represents the role of unresolved mesoscale eddies. Depending on $\mathrm{C}, S_{\mathrm{C}}$ accounts for gas exchange, river discharge, flux to the sediments, gravitational sinking, and other biological processes.

[9] Vertical integration of equation (1) from the surface of the ocean to the depth of the mixed-layer $h$ leads to

$h \cdot \partial_{t} \mathrm{C}_{h}=-\mathrm{C}_{h} \cdot\left(\partial_{t} h+\boldsymbol{u}_{h} \cdot \nabla_{H} h+w_{h}\right)+\left(k_{z} \partial_{z} \mathrm{C}\right)_{h}+\int_{0}^{h} E_{\mathrm{C}} \mathrm{d} z+\int_{0}^{h} S_{\mathrm{C}} \mathrm{d} z$

where $\mathrm{C}_{h}, \boldsymbol{u}_{\boldsymbol{h}}$, and $w_{h}$ are the values of $\mathrm{C}, \boldsymbol{u}$, and $w$ at the mixed-layer base. The first term in the right-hand side in equation (2) is equal to $\mathrm{C}_{h}$ multiplied by the instantaneous subduction rate [Cushman-Roisin, 1987] associated with local change in mixed-layer depth $\left(-\partial_{t} h\right)$, lateral advection across the sloping mixed-layer base $\left(-\boldsymbol{u}_{\boldsymbol{h}} . \nabla_{H} h\right)$, and vertical advection at the mixed-layer base $\left(-w_{h}\right)$. The second term, $\left(k_{z} \partial_{z} \mathrm{C}\right)_{h}$, represents the vertical diffusion of $\mathrm{C}$ across the mixed-layer base, while the third term accounts for 
Table 1. Data Sets Used for the Computation of the Data-Based Advective Transfers of DIC and the Nominal Resolution at Which They Were Available

\begin{tabular}{lccccc}
\hline & $\begin{array}{c}\text { Horizontal } \\
\text { Resolution }\end{array}$ & $\begin{array}{c}\text { Vertical } \\
\text { Resolution }\end{array}$ & $\begin{array}{c}\text { Time } \\
\text { Resolution }\end{array}$ & $\begin{array}{c}\text { Period } \\
\text { of Reference }\end{array}$ & Reference \\
\hline DIC & $1^{\circ}$ & 33 Levels & Year & $1990 \mathrm{~s}$ & GLODAP, Key [2004] \\
Anthropogenic $\mathrm{CO}_{2}$ & $1^{\circ}$ & 33 Levels & Year & $1990 \mathrm{~s}$ & $\begin{array}{c}\text { GLODAP, Key [2004] } \\
\text { Mixed-layer depth }\end{array} 2^{\circ}$ \\
Horizontal velocities & $1 / 3^{\circ}$ & Surface & Month & $1961-2008$ & de Boyer Montégut et al. [2004] \\
Wind stress & $1^{\circ}$ & Surface & 6 h & 2002-2011 & AVISO \\
\hline
\end{tabular}

lateral eddy-induced fluxes across the sloping mixed-layer base. Finally, the last term measures the rate of change of $\mathrm{C}$ due to biological processes, sinking, air-sea flux, and river discharges.

[10] The annual balance between carbon sources and sinks in the time-varying mixed layer is computed by integrating equation (2) over the year [Valdivieso Da Costa et al., 2005; Karleskind et al., 2011b]:

$$
\begin{aligned}
\int_{0}^{1 \mathrm{yr}} & {[\underbrace{-\left(w_{h}+\boldsymbol{u}_{h} \cdot \nabla_{H} h\right) \mathrm{C}_{h}}_{\text {advection }}+\underbrace{\left(k_{z} \partial_{z} \mathrm{C}\right)_{h}-\mathrm{C}_{h} \cdot \partial_{t} h}_{\text {vertical mixing }}} \\
& +\underbrace{\int_{0}^{h} E_{\mathrm{C}} \mathrm{d} z}_{\text {eddy mixing }}+\underbrace{\int_{0}^{h} S_{\mathrm{C}} \mathrm{d} z}_{\text {others }}] \mathrm{d} t=0
\end{aligned}
$$

[11] Three types of physical processes are considered from equation (3): advection, vertical mixing, and eddy mixing. Note that the following, vertical diffusion at the base of the mixed layer and entrainment due to changes in mixedlayer depth, are merged into what we generically refer to as vertical mixing. The evaluation of these three terms in the model is described in the next paragraph.

\subsection{Carbon Flux Diagnostics From a Preindustrial Model Simulation}

[12] The ocean hydrodynamical model used here is the global configuration (ORCA) of Nucleus for European Modelling of the Ocean (NEMO v3.2) [Madec, 2008] coupled to the Louvain-la-Neuve sea ice model (LIM2) [Timmermann et al., 2005]. The quasi-isotropic tripolar grid [Madec and Imbard, 1996] has a nominal resolution of $2^{\circ}$ with increased $0.5^{\circ}$ latitudinal resolution at the equator and is referred to as ORCA2. In the vertical, the grid has 31 levels with 10 levels in the upper $100 \mathrm{~m}$. The vertical subgrid-scale mixing parameterizations include a representation of mixed layer dynamics by an improved Turbulent Kinetic Energy (TKE) closure [Madec, 2008] and additional subgrid-scale mixing parameterizations such as a Laplacian viscosity, an iso-neutral Laplacian diffusivity, and the use of a GM-scheme to mimic the effect of subgrid-scale eddy processes [Gent and McWilliams, 1990].

[13] The hydrodynamic model has been coupled online to the Pelagic Interaction Scheme for Carbon and Ecosystem Studies (PISCES) [Aumont and Bopp, 2006]. PISCES includes a simple representation of the marine ecosystem and describes the cycles of carbon and of the main marine nutrients $(\mathrm{N}, \mathrm{P}, \mathrm{Fe}$, and $\mathrm{Si})$. The carbonate chemistry follows the Ocean Carbon-Cycle Model Intercomparison Project protocols (www.ipsl.jussieu.fr/OCMIP). The air-sea $\mathrm{CO}_{2}$ exchange is calculated with the bulk exchange formula and Wanninkhof [1992] relationship for the gas transfer velocity.
[14] ORCA2-PISCES is forced by the Consortium for Oceanic Research and Education (CORE2) Normal Year Forcing (see Large and Yeager [2008], for a detailed description of the forcing) and by atmospheric $\mathrm{CO}_{2}$ that is fixed at its preindustrial level of $278 \mathrm{ppm}$. A 1000 year physics only spin-up procedure was carried out with the same forcing. For the biogeochemistry, we used a 3000 year off-line spin-up of PISCES [Aumont and Bopp, 2006]. We then ran an additional 50 years in online mode and here we analyze the last year of this simulation. This spin-up procedure led to a drift in the mixed-layer DIC concentration of $0.004 \%$ per year, which indicated that the model mixed-layer carbon budget was close to equilibrium. Though the model atmospheric $\mathrm{CO}_{2}$ is set to preindustrial level, the nominal period for the CORE normal year forcing covers the second half of the twentieth century. With this caveat in mind, the simulation is referred to as preindustrial. This is justified because the influence of climate change on $\mathrm{CO}_{2}$ uptake by the ocean for the historical period is shown to be of second order compared to the direct influence of the change in atmospheric $\mathrm{CO}_{2}$ [Le Quere et al., 2010].

[15] The different terms of equation (3) were evaluated online. Vertical diffusion of carbon was computed with the vertical diffusion coefficient $k_{z}$ derived from the TKE closure. Eddy mixing of carbon $E_{\mathrm{C}}$ was parametrized as the sum of isoneutral diffusion (with a coefficient varying in the range 1-2500 $\mathrm{m}^{2} \mathrm{~s}^{-2}$ depending on baroclinicity) [Madec, 2008] and advection by GM bolus velocities. Carbon transfers were sorted into four categories: particulate organic carbon (POC), which comprises the sum of phytoplankton, zooplankton, and detritus, dissolved organic carbon (DOC), particulate inorganic carbon (PIC, i.e., $\mathrm{CaCO}_{3}$ ), and DIC. In ORCA2-PISCES, two extra terms enter equation (3), which have been omitted for simplification: those account for the response to evaporation minus precipitation and for the change in volume in response to free surface variations; in our budgets, these terms were added to total vertical mixing.

\subsection{Data-Based Evaluation of DIC Physical Transfers}

[16] DIC fluxes were also independently evaluated from monthly climatological data of the contemporary ocean corrected, for DIC, by anthropogenic carbon inventories (Table 1). Our choice was to use data sets that had the largest global coverage and captured time and space scales comparable with those of the model. Thus, for horizontal velocities, we used Archiving, Validation, and Interpretation of Satellite Oceanographic data (AVISO) gridded surface absolute geostrophic velocities derived from altimetry (http://www.aviso.oceanobs.com/duacs/) and assumed they were constant in the mixed-layer. Vertical velocities were inferred from CORE2 Normal Year Forcing wind stresses 
[Large and Yeager, 2008] (i.e., the model wind forcing) assuming Ekman balance. On the vertical, velocities were assumed to be constant below the Ekman layer and to decrease linearly to zero toward the surface. We used the gridded level 3 Mixed-Layer Depth (MLD) products of de Boyer Montégut et al. [2004], updated in 2009. These MLD products were computed from in situ measurements of temperature and salinity, including more than 5 million temperature profiles from the World Ocean Database 2009 (WOD09), World Ocean Circulation Experiment, and ARGO (www.argo.net) programs. For DIC, we used the Global Ocean Data Analysis Project (GLODAP) climatology [Key, 2004] corrected to the preindustrial period by removing the GLODAP anthropogenic carbon inventory. Following Mahadevan et al. [2011], monthly DIC profiles were constructed from the annual mean GLODAP profile by averaging DIC from the surface down to the monthly depth of the mixed-layer base. All data were interpolated on the same $1^{\circ} \times 1^{\circ}$ grid.

[17] Due to the breakdown of the Ekman and geostrophic balances in the equatorial band (broadly $10^{\circ} \mathrm{N}-10^{\circ} \mathrm{S}$ ), the data-based advective transfers of DIC could not be evaluated there. Moreover, in the above data climatologies, the coverage in the Arctic Ocean is too low to allow us to provide a reliable data estimate in this region. Note that data availability has constrained us to use climatologies for the ocean physics that corresponds to different reference periods (Table 1). This caveat implies that the climatological state is not strictly representative of a preindustrial ocean.

[18] We assumed an Ekman layer depth of $50 \mathrm{~m}$, used the MLD product based on a fixed density criterion of $0.03 \mathrm{~kg} / \mathrm{m}^{3}$ and applied a $5^{\circ} \times 5^{\circ}$ window filter for the mixed layer and horizontal velocity fields to smooth out small-scale inconsistencies between the two data sets. Error bars associated with the sensitivity of the estimates to the different choices made in the calculation were computed by varying the Ekman layer depth $(50 / 100 \mathrm{~m})$, the MLD product (fixed density threshold, variable density threshold, fixed temperature threshold), and the smoothing window $\left(5^{\circ} \times 5^{\circ} / 2^{\circ} \times\right.$ $\left.2^{\circ}\right)$. We find that these errors are of the order of $20 \%$ or less. It should be stressed that our estimated errors are underestimated because they do not account for the errors on each individual data product.

[19] With the above data sets and assumptions, we were able to provide data-based estimates of the DIC subduction and obduction by horizontal and vertical advection. Given the large variability in observed rates of vertical and eddy mixing in the ocean, data-based evaluation of the vertical mixing and eddy mixing fluxes is more hazardous. Sallée et al. [2010] attempted an evaluation of the eddy flux in the Southern Ocean based on the GM parametrization but with large uncertainties. Here we choose not to pursue the databased estimates of eddy and vertical mixing. These terms are small when compared with advective fluxes in the model results presented below.

\section{Results}

[20] Our objective is to derive a revised preindustrial mixed-layer carbon budget, at the regional and global scale, with emphasis on two terms of this budget that have received less attention: the physical fluxes of DIC and of organic carbon (dissolved and particulate). These terms were evaluated from the model simulation, which allowed the derivation of a closed and consistent budget. A data-based evaluation of the advective fluxes of DIC is also provided to strengthen the results obtained with the model alone. We start with a mechanistic examination of the physical processes driving these fluxes (i.e., advection, eddy mixing and vertical mixing, sections 3.1 and 3.2) and compare our model-based and data-based estimates. Then we compare physical carbon fluxes to the other carbon fluxes in and out of the surface mixed layer (i.e., air-sea $\mathrm{CO}_{2}$ flux and sedimentation, section 3.3) from which we derive regional (section 3.4) and global (section 3.5) budgets.

\subsection{Physical Transfers of DIC: Driving Mechanisms}

[21] First, we examine the contributions of the different terms involved in the physical transfer of DIC across the mixed-layer estimated with ORCA2-PISCES (Figure 2). Horizontal advection patterns colocate with areas where mean currents cross sloping mixed layer, which explain why they have a relatively narrow scale along the meridional direction (Figure 2a). Horizontal advection plays a key role at the equatorial divergence: on either side of the equator, divergence across the sloping mixed layer causes a strong obduction of DIC. The contribution of horizontal advection is also large in regions of strong currents; thus, in the North Atlantic and North Pacific, it causes DIC subduction along the Gulf stream and Kuroshio southern flanks and DIC obduction along their northern flanks. In the North Atlantic, this result is consistent with previous results highlighting the obduction of nutrients [Williams et al., 2006], the removal of DIC associated with the formation of $18^{\circ} \mathrm{C}$ subtropical mode waters in the West [Bates et al., 2002; Oschlies and Kähler, 2004; Palter et al., 2005], and the formation of $13^{\circ} \mathrm{C}$ subpolar mode waters in the East [Lévy, 2005; Karleskind et al., 2011b]. In the North Pacific, our result is consistent with the lateral removal of carbon by geostrophic flow in the transition zone identified by Ayers and Lozier [2012]. In the Southern Ocean, horizontal advection generates alternate areas of DIC obduction and subduction along the path of the Antarctic Circumpolar Current (ACC). This is consistent with the similar diagnostic of Sallée et al. [2010] using a MLD product specifically constructed for the Southern Ocean. On the other hand, vertical advection patterns mostly ensue from the wind-induced Ekman pumping and tend to have a wider scale than horizontal advection patterns (Figure 2b). Vertical advection obducts DIC in regions of upwelling, i.e., in subpolar gyres, in the Southern Ocean south of $50^{\circ} \mathrm{N}$, along eastern boundaries and at the equator, and subducts DIC in regions of negative Ekman pumping, i.e., in subtropical gyres. As noted before, the coarse resolution of our model does not allow explicit resolution of eddy mixing and this term is parametrized. With this caveat in mind, we find that the contribution of eddy mixing is very localized and partly counteracts horizontal advection in the Gulf Stream, Kuroshio, and ACC regions (Figure 2d). The contribution of vertical mixing is one order of magnitude smaller than the other terms (Figure $2 \mathrm{c}$ ). The magnitude of the vertical diffusion coefficient at the mixed-layer base in our model is always larger than $10^{-4} \mathrm{~m}^{2} \mathrm{~s}^{-2}$, in agreement with data reported in the literature [i.e., $W u$ et al., 2011]. It is thus the weak DIC gradient at the base of the mixed layer that explains the low contribution of vertical 


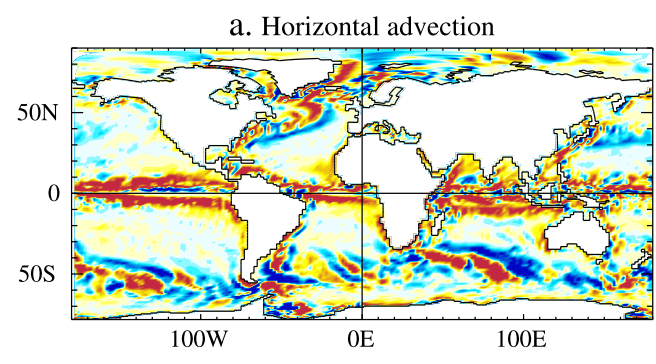

c. Vertical mixing

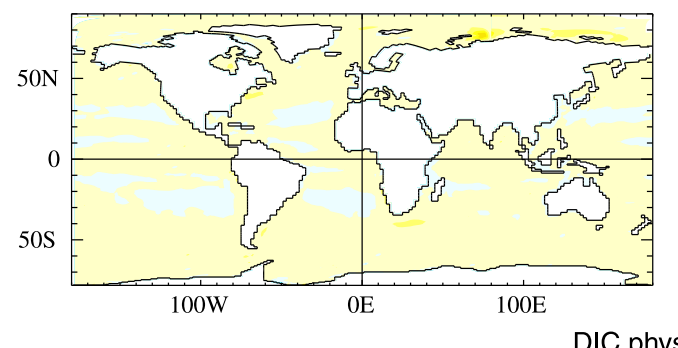

b. Vertical advection

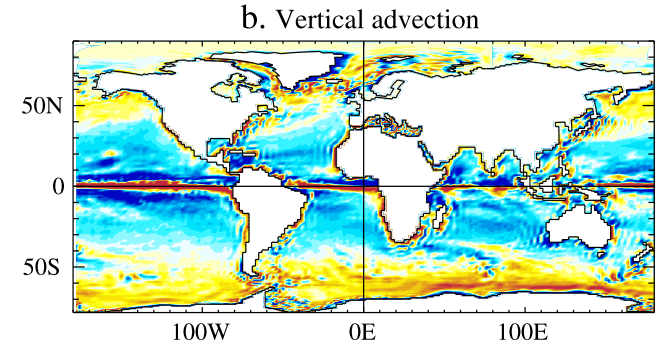

d. Eddy mixing

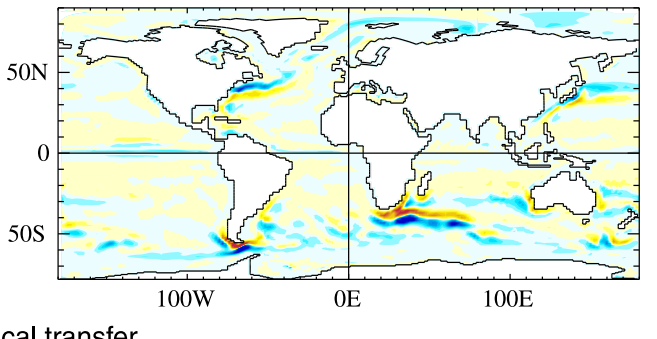

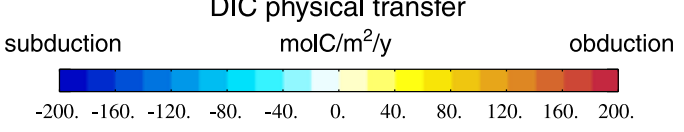

Figure 2. Annual physical transfers of DIC in the ORCA2-PISCES preindustrial model simulation due to (a) horizontal advection, (b) vertical advection, (c) vertical mixing, and (d) eddy mixing. We use the convention that carbon fluxes directed to the mixed layer are counted positively.

mixing. At the scale of ocean basins, the lead process for DIC transfer is vertical advection except in the tropical band (between $18^{\circ} \mathrm{N}$ and $18^{\circ} \mathrm{S}$ ) where, rather counterintuitively, horizontal advection dominates. This is highlighted by budgets performed over 10 wide regions covering the world's ocean (Figure 3a). In fact, although we have just seen that horizontal advection can locally play an important role, adjacent regions of obduction and subduction (for instance, on either side of the Gulf Stream) tend to compensate at larger scale. For instance, in the temperate North Atlantic $\left(18^{\circ} \mathrm{N}-\right.$ $49^{\circ} \mathrm{N}$ ), the net effect of horizontal advection is close to zero due to compensations between obduction of $\sim 10 \mathrm{TgC} \mathrm{yr}^{-1}$ and subduction of $\sim-10 \mathrm{TgC} \mathrm{yr}^{-1}$. This compensation is also true for vertical advection; in the Southern Ocean $\left(44^{\circ} \mathrm{S}-70^{\circ} \mathrm{S}\right)$, the net vertical obduction of $\sim 20 \mathrm{TgC}^{-1}$ results from a balance between vertical obduction of $\sim 40 \mathrm{TgC}^{-1}$ (occurring mostly south of $50^{\circ} \mathrm{S}$ ) and vertical subduction of $\sim-20 \mathrm{TgC} \mathrm{yr}^{-1}$ (between $44^{\circ} \mathrm{N}$ and $50^{\circ} \mathrm{N}$ ). Another example is in the tropical Pacific, where very localized obduction of DIC along the equator $\left(\sim 40 \mathrm{TgC} \mathrm{yr}^{-1}\right)$ is counteracted by subduction on either side of the equator $\left(\sim-70 \mathrm{TgC} \mathrm{yr}^{-1}\right)$. Thus the net transfer by vertical advection is negative $\left(\sim-30 \mathrm{TgC} \mathrm{yr}^{-1}\right)$ and in fact smaller than the net transfer by horizontal advection $\left(\sim 50 \mathrm{TgC}^{-1}\right)$. It should thus be stressed that the basin-scale numbers in Figure 3 hide a strong degree of variability at the local scale (see more examples in the "supporting information Figure S1").

[22] Data-based estimates of DIC transfers lead to similar numbers to model-based estimates (Figure 3b, see also global maps in the supporting information Figure S2). Importantly, the strongest agreement is found for vertical advection, which is the lead process away from the tropical band, where data-based estimates are not available. This strong agreement is related to the use of the same climatological wind product in both estimates. The misfit between data and model estimates is larger for horizontal advection, in part because the uncertainties in the data-based estimates are proportionally larger. In fact, besides the tropical band and the Arctic Ocean where data estimates are missing, the main differences $(\sim 40 \%)$ are found in coastal regions of the temperate North Atlantic and temperate south Pacific (not shown) where processes are poorly resolved in both estimates anyway.

[23] To sum up, our model estimates show that on gyre scales and smaller, horizontal advection is the strongest term driving the physical transfer of DIC (Figure 2). After averaging over wide regions, vertical advection becomes dominant and this is confirmed by the data estimates (Figure 3). The exception is the tropical band region where the contribution of horizontal advection dominates.

\subsection{Physical Transfers of Organic Carbon (POC+DOC): Driving Mechanisms}

[24] Ocean circulation is also responsible for the physical transfer of organic carbon across the mixed layer, both for particulate and dissolved forms (Figure 3c, see also global maps in the supporting information Figure S3). The patterns of physical transfer of organic carbon driven by horizontal advection, vertical advection, and eddy mixing are similar to those of DIC. However, unlike DIC, vertical mixing makes a significant contribution because of the strong gradient of organic carbon at the base of the mixed layer. This large contribution is due to winter entrainment of organic carbon. This occurs mostly in regions where productivity shows a strong seasonality driven by the seasonality of the mixed layer, such as the North Atlantic and North Pacific subpolar gyres and the Southern Ocean. In these regions, organic carbon builds up in the mixed layer when it is stratified 


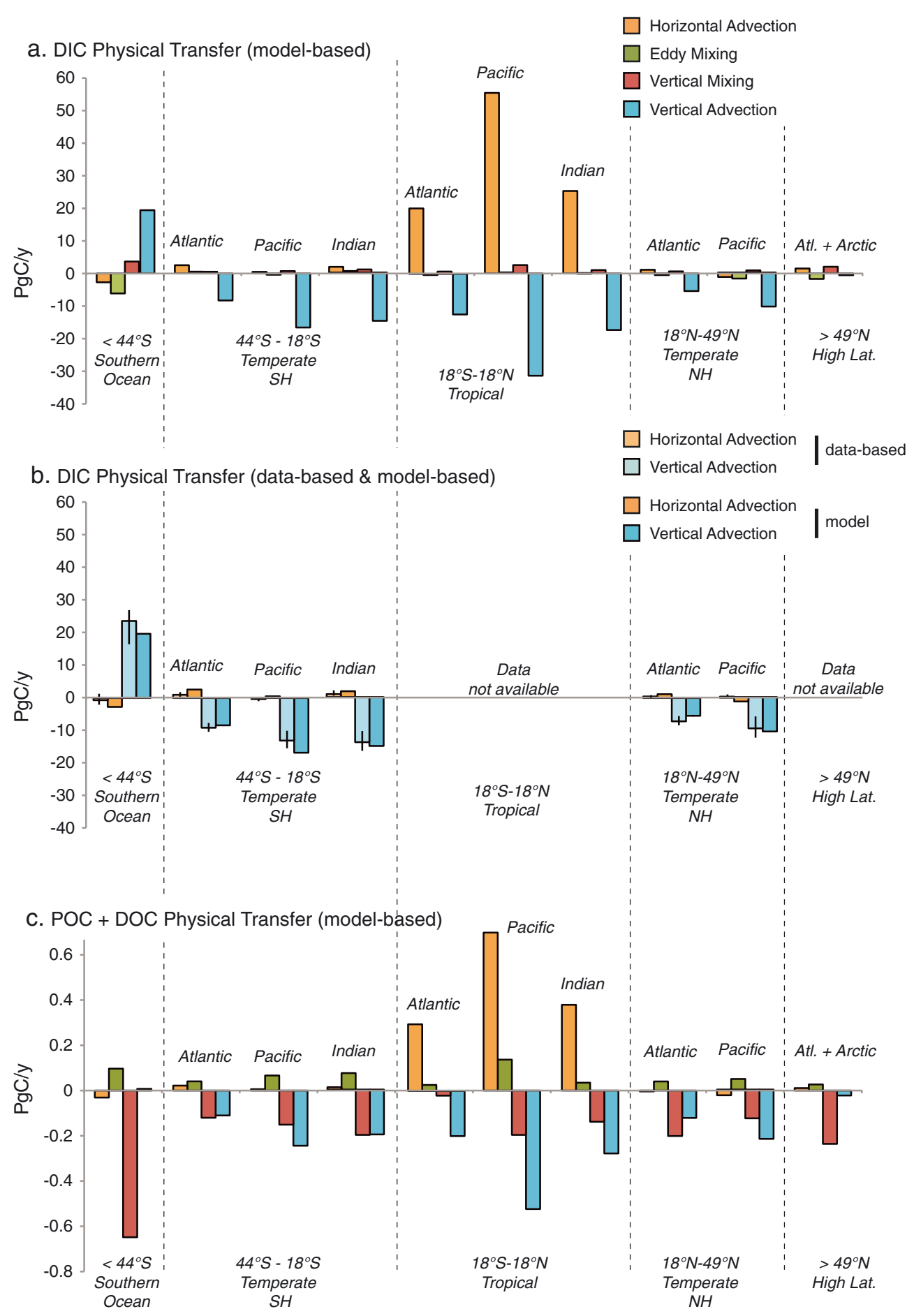

Figure 3. Contributions of different physical mechanisms to the DIC and OC physical transfers, averaged over 10 regions of the world's ocean [Gruber et al., 2009], ordered by latitude and ocean basin. (a) DIC physical transfer estimated in ORCA2-PISCES. (b) Comparison of the data-based and modelbased estimates of the physical transfer of DIC by horizontal and vertical advection, in regions where both estimates are available. Error bars in the data-based estimates relate to different assumptions made to compute the transfers (see Method section for more details). (c) Physical transfer of total organic carbon in ORCA2-PISCES. 
a. Physical Transfer of DIC

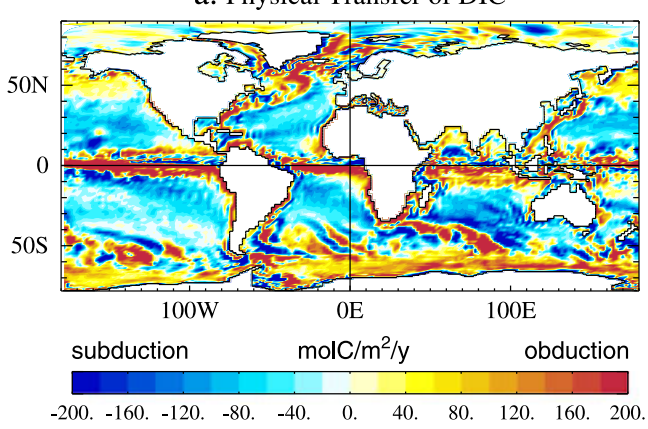

c. air-sea $\mathrm{CO} 2$ flux

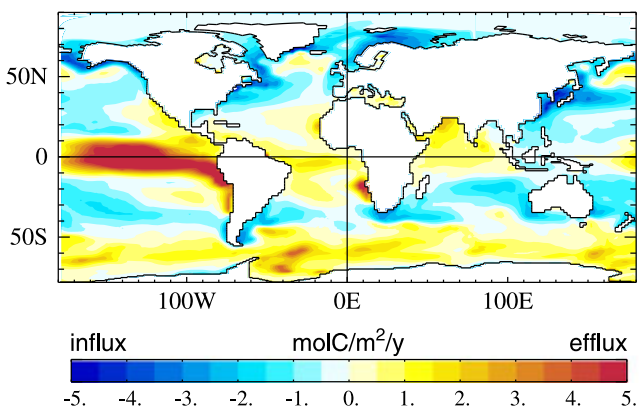

b. Physical Transfer of OC

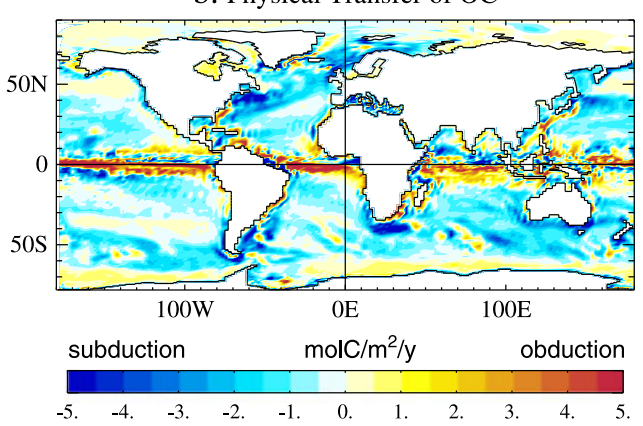

d. Biological Transfer

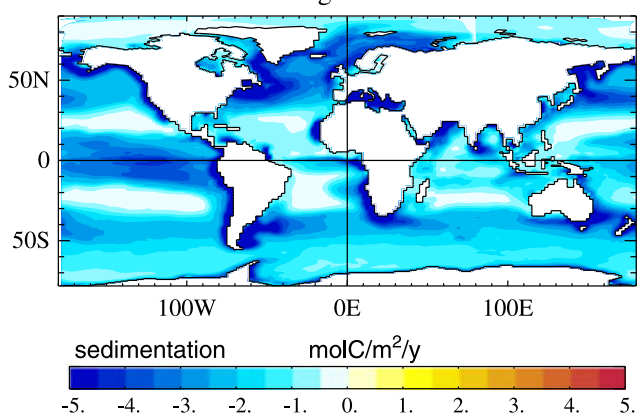

Figure 4. Annual physical transfers of (a) DIC and (b) organic carbon (OC) across the mixed layer, (c) air-sea $\mathrm{CO}_{2}$ flux, and (d) biological transfer (sedimentation of POC + PIC) in the ORCA2-PISCES preindustrial model simulation. We use the convention that upward carbon fluxes are counted positively (i.e., obduction and efflux). Note the different color scale used in Figure 4a.

(in spring and summer) and is entrained between fall and winter when the mixed layer deepens. This is clearly seen at the regional scale, where the contribution from vertical mixing largely dominates in subpolar gyres and has a contribution of similar amplitude to that of vertical advection in temperate regions. The tropical band is the only region where organic carbon is obducted back to the mixed layer through horizontal advection at the equatorial divergence.

\subsection{Carbon Transfers in and out of the Surface Mixed Layer}

[25] Here we describe how carbon enters and exits the mixed layer. The pathways of the total DIC and organic carbon physical fluxes are examined and compared to the air-sea and sedimentation fluxes (Figure 4).

[26] After adding up contributions from all physical processes, we find that the patterns for the total physical transfer of DIC are characterized by subduction in subtropical gyres and in specific spots along the ACC and by obduction in the subpolar gyre along the northern flanks of the Gulf stream and Kuroshio, in the Southern Ocean south of $50^{\circ} \mathrm{S}$, in the tropical band and along eastern upwelling regions (Figure 4a). These patterns are consistent with the subduction/obduction patterns of water masses identified in previous studies [i.e., Marshall et al., 1993; Qiu and Huang, 1995; de Miranda et al., 1999; Sallée et al., 2010; Qu et al., 2010; Lee et al., 2011; Trossman et al., 2012]. On the other hand, the total annual physical transfer of organic carbon (Figure 4b) is dominated by subduction, except in the tropical band where organic material is brought back to the surface. As mentioned before, the difference with DIC ensues from the large contribution of vertical mixing to the total physical transfer of organic carbon. In agreement with previous estimates [Mikaloff Fletcher et al., 2007], the preindustrial air-sea $\mathrm{CO}_{2}$ flux estimated in the model (Figure 4c) is dominated by $\mathrm{CO}_{2}$ uptake at temperate latitudes and by the release of $\mathrm{CO}_{2}$ to the atmosphere in the tropics and Southern Ocean. Moreover, consistent with other estimates [Laws et al., 2000; Schlitzer, 2002, 2004; Dunne et al., 2005], the net sedimentation flux (Biological Transfer, Figure 4d) presents large values over the most productive regions (mainly North Atlantic, North Pacific, Equatorial Pacific, and Southern Ocean).

[27] The first important remark that emerges from the comparison between these four forms of carbon transfers concerns their relative magnitudes. Overall, the physical transfer of DIC has an amplitude which is between one and two orders of magnitude larger than the other fluxes. This ensues from the fact that DIC is by far the most abundant form of carbon. Hence, there is a factor $\sim 50-100$ between the amount of $\mathrm{CO}_{2}$ exchanged at the air-sea interface and the amount of DIC exchanged at the base of the mixed layer. Also, there is similar factor between the biological transfer of carbon by sedimentation and the physical transfer of DIC by obduction/subduction. On the other hand, it is also remarkable that subduction of organic carbon has a magnitude which is comparable to sedimentation.

[28] This comparison also enables us to reveal more clearly the complex route followed by carbon along its oceanic cycle. Carbon enters the ocean at the air-sea interface in the temperate ocean (Figure 4c); these areas generally correspond to regions of strong biological trans- 


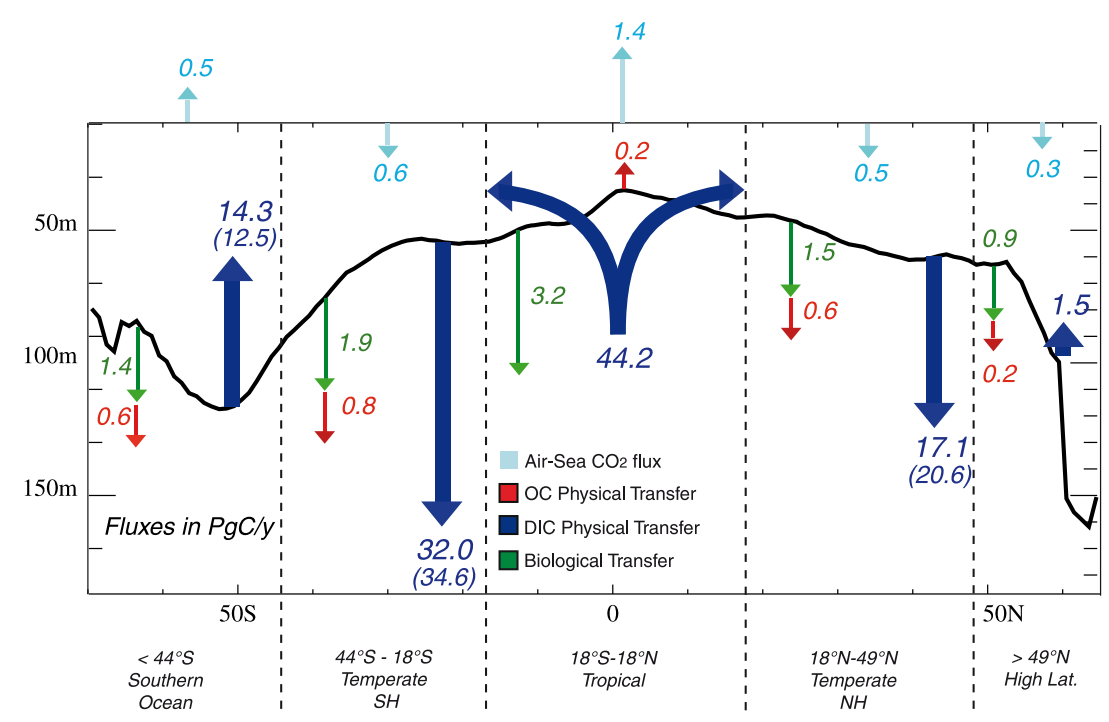

Figure 5. Schematic of the main carbon transfers across the mixed-layer interface, averaged by latitude bands, including the air-sea $\mathrm{CO}_{2}$ flux, the physical transfer of organic carbon (OC), the physical transfer of DIC, and the biological transfer (sedimentation) in the ORCA2-PISCES preindustrial model simulation (except for the numbers in brackets which refer to the data estimates, when available). The surface of the arrows (length $\times$ thickness) are proportional to the fluxes. The black line shows the zonal annual mean mixed-layer depth from the climatology of de Boyer Montégut et al. [2004].

fer (Figure 4d). At the scale of ocean gyres or less, there is no systematic correspondence between these regions of $\mathrm{CO}_{2}$ influx and regions of subduction. This ensues from the important role of horizontal advection in the subduction of DIC at the local scale revealed earlier. In fact, our analysis reveals that the annual patterns of obduction/subduction vary on a smaller scale than those of air-sea $\mathrm{CO}_{2}$ exchanges. An illustrative example is the case of the temperate North Atlantic. South of the Gulf stream, subduction and sedimentation both promote the efficiency of carbon penetration. But north of the Gulf Stream, strong obduction of DIC is opposed to the biological transfer and opposed to the airsea flux. On the other hand, the main return pathways to the atmosphere are in the equatorial and Southern Ocean regions, both characterized by a large efflux (Figure 4c) and large obduction (Figure 4a). But here again, there is no systematic correspondence between efflux and obduction at subregional scale, as revealed by the presence of localized subduction hot spots in these two regions. This analysis thus reveals that carbon transfers across the mixedlayer base involve much larger amounts of carbon than at the air-sea interface; at the local scale, there are no systematic colocations between areas of large oceanic $\mathrm{CO}_{2}$ uptake (resp. release) and/or areas of strong subduction of $\mathrm{CO}_{2}$ (resp. obduction), and this decorrelation is mostly due to horizontal advection.

\subsection{Regional Mixed-Layer Carbon Budget}

[29] We now examine the carbon transfers in and out of the mixed layer at the scale of large ocean regions (Figure 5). First, at the regional scale, the air-sea $\mathrm{CO}_{2}$ flux and the DIC physical transfer are always of the same sign (i.e., either upward or downward, light blue and dark blue arrows in Figure 5). This ensues from the dominance of vertical advection (and the canceling out of horizontal advection) at regional scale mentioned before. One exception is north of $49^{\circ} \mathrm{N}$ where both fluxes are small. Hence, in temperate regions, where $\mathrm{CO}_{2}$ enters the ocean at the air-sea interface, the physical transfer of DIC contributes to the penetration of carbon toward the interior of the ocean and thus adds to the biological transfer; actually, in these regions, the penetration originating from physical processes represents $\sim 90 \%$ of the total penetration of carbon below the mixed layer. This physical transfer is also $\sim 50$ times larger than the air-sea flux. Note also the agreement between data and model estimates of DIC physical transfer at the regional scale (with differences less than $20 \%$, numbers in brackets in Figure 5) which confirm the above results. This large subduction is partly compensated by obduction of DIC in the tropics and in the Southern Ocean, where the airsea flux is directed toward the atmosphere. We can estimate that $75 \%$ of this net DIC obduction occurs in the tropical band and the remaining 25\% in the Southern Ocean. Second, at temperate and high latitudes, the contribution of organic carbon subduction to the total export of organic carbon is always significant $(\sim 30 \%$, red and green arrows in Figure 5).

\subsection{Global Mixed-Layer Carbon Budget}

[30] Finally, these results are used to derive a revised global preindustrial surface ocean carbon budget (Figure 6, see also Table S1). Across the surface of the ocean, and consistent with previous estimates [Sarmiento and Gruber, 2006], the riverine carbon input $\left(0.8 \mathrm{PgC} \mathrm{yr}^{-1}\right)$ is balanced by $\mathrm{CO}_{2}$ efflux to the atmosphere $\left(-0.5 \mathrm{PgC} \mathrm{yr}^{-1}\right)$ and loss to sediments $\left(-0.3 \mathrm{PgC} \mathrm{yr}^{-1}\right)$. The net preindustrial air-sea efflux results from a balance between regions of influx where the annual mean value of the air-sea $\mathrm{CO}_{2}$ flux is positive $\left(+1.9 \mathrm{PgC} \mathrm{yr}^{-1}\right)$ and regions of efflux where it is negative $\left(-2.4 \mathrm{PgC} \mathrm{yr}^{-1}\right)$. Note that the contribution of air-sea fluxes 


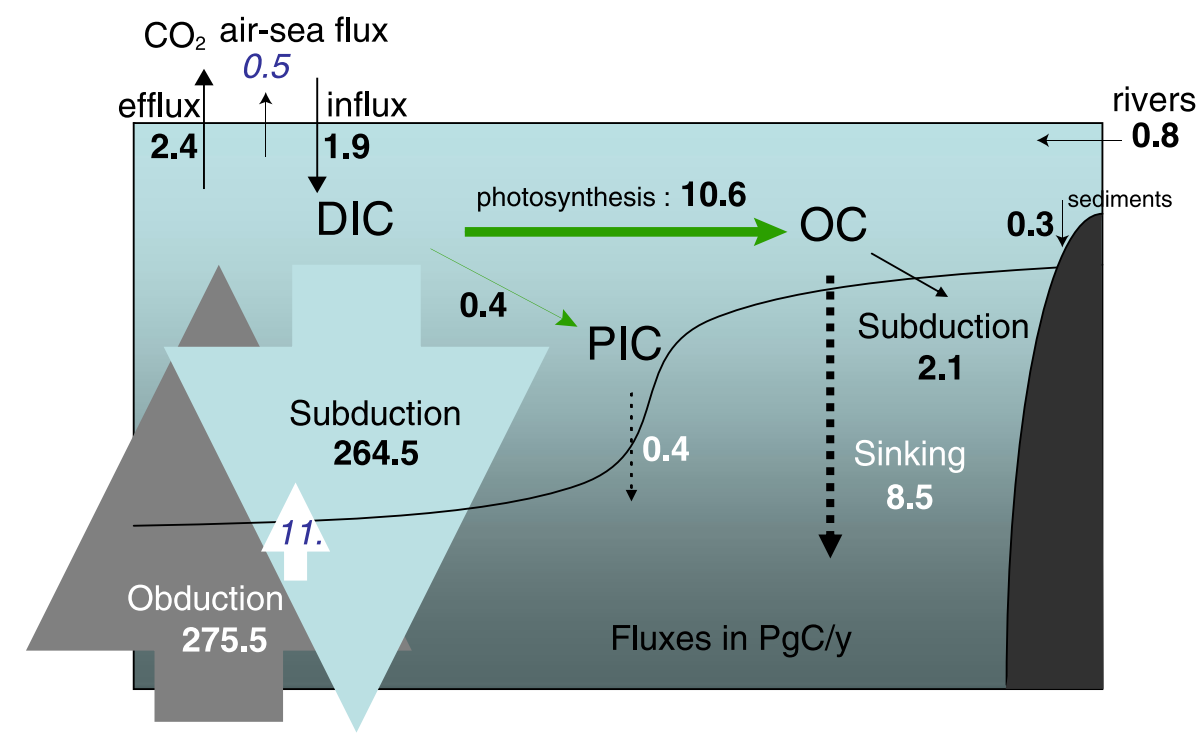

Figure 6. Mixed-layer carbon budget for the global ocean in the ORCA2-PISCES preindustrial simulation. Thickness of the arrows is proportional to the values of the fluxes. The separation between subduction and obduction of DIC and between air-sea $\mathrm{CO}_{2}$ efflux and influx is based on the sign of the annual mean flux; it reflects differences in the direction of the annual flux at the regional scale; the net flux at the global scale is indicated with oblique blue characters. DIC: dissolved inorganic carbon, OC: dissolved and particulate organic carbon, PIC: particulate inorganic carbon $\left(\mathrm{CaCO}_{3}\right)$.

is computed using $F=k s\left(\mathrm{pCO} 2_{\mathrm{atm}}-\mathrm{pCO} 2_{\text {oce }}\right)$ (with $k$ the gas exchange coefficient, $s$ the solubility, and $\mathrm{pCO} 2_{\text {atm }}$ and $\mathrm{pCO} 2_{\text {oce }}$ the partial pressure of $\mathrm{CO}_{2}$ in the atmosphere and ocean, respectively), which explains why it is not directly comparable to the one of Sarmiento and Gruber [2006] (their Figure 10.1.1), where the net efflux is split into $k s \mathrm{pCO} 2_{\text {oce }}=-70 \mathrm{PgC} \mathrm{yr}^{-1}$ and $k s \mathrm{pCO} 2_{\text {atm }}=70.6 \mathrm{PgC} \mathrm{yr}^{-1}$.

[31] Across the mixed layer, the loss of biotically produced material $\left(-11 \mathrm{PgC} \mathrm{yr}^{-1}\right)$ is balanced by a net, physically mediated obduction of inorganic carbon $\left(11 \mathrm{PgC} \mathrm{yr}^{-1}\right)$. Note that this estimate is the same as that of Sarmiento and Gruber [2006] for a slightly different choice of surface boundary layer (mixed layer here versus $100 \mathrm{~m}$ in their case).

[32] Two important results emerge from this carbon budget and relate to the physical transfers of organic and inorganic carbon in and out of the mixed layer. First, our model suggests that $\sim 20 \%\left(2.1 \mathrm{PgC} \mathrm{yr}^{-1}\right)$ of the total flux of organic material out of the mixed layer $\left(10.6 \mathrm{PgC} \mathrm{yr}^{-1}\right)$ results from subduction; in other words, accounting only for sinking material is an underestimation of this flux by $\sim 20 \%$. As noted before, this number is actually closer to $\sim 30 \%$ out of the tropical band. Second, the net obduction of dissolved inorganic carbon $\left(11 \mathrm{PgC} \mathrm{yr}^{-1}\right)$ results from the difference between gross subduction $\left(-264.5 \mathrm{PgC} \mathrm{yr}^{-1}\right)$ and gross obduction fluxes $\left(+275.5 \mathrm{PgC} \mathrm{yr}^{-1}\right)$, which are larger by one order of magnitude. This emphasizes the contrast between source regions where DIC is supplied in large amounts and sink regions where DIC is loss in similar amounts through physical mechanisms (Figure 3a). These numbers $\left(+275.5 /-264.5 \mathrm{PgC} \mathrm{yr}^{-1}\right)$ are much larger than earlier calculations based on box models and/or global ventilation rates that have been reported in the TAR $\left(+40 /-30 \mathrm{PgC} \mathrm{yr}^{-1}\right)$ [Prentice et al., 2001] and AR4 (+100/-90 $\left.\mathrm{PgC} \mathrm{yr}^{-1}\right)$ [Denman et al., 2007].

\section{Discussion}

\subsection{How Do Carbon Transfers Relate to Carbon Pumps?}

[33] The traditional paradigm is that the ocean interior is a large carbon repository due to a combination of oceanic processes referred to as carbon pumps [Volk and Hoffert, 1985], namely the solubility pump, the soft tissue pump, and the carbonate pump which we describe in turns (Figure 1a). The solubility pump is due to the solubility difference of $\mathrm{CO}_{2}$ in warm and cold waters. It consists in the subduction of DIC enriched, cold waters and the obduction of this preformed DIC back to the surface. In addition, photosynthesis in the surface ocean converts DIC and nutrients into organic carbon, often associated with calcium carbonate particulate inorganic material, ultimately leading to a transfer of carbon to the ocean interior through sinking of organic and inorganic particles. The soft tissue pump refers to the sinking of the organic particles which are remineralized back into DIC at depth (the so-called remineralized DIC), while the carbonate pump results from the dissolution of calcium carbonate in the particles that sink. The two biological pumps also encompass a physical transfer of the remineralized DIC back to the surface layers. The action of the three carbon pumps taken all together results in an excess of DIC in the deep ocean with respect to the surface. Their strength is quite naturally measured by the DIC gradient between the surface and deep ocean. In a more nuanced manner, the breaking into components due to the soft tissue, carbonate, and solubility pumps of the DIC profile, using profiles of phosphate, oxygen, and alkalinity, allows the relative contributions of the different pumps to be quantified [Sarmiento and Gruber, 2006; Marinov et al., 2008a, 2008b; Williams and Follows, 2011]. A further refinement is to separate the preformed from the reminer- 
alized DIC [Ito and Follows, 2005; Devries et al., 2012], which allows to take into account the role of ocean circulation in an integrated manner since the presence of preformed carbon at depth implies that it has been subducted from the surface. Our view of carbon transfers is complementary to the description of the above carbon pumps based on DIC profiles; it includes explicit estimates of carbon exchanges between the surface and ocean interior driven by the ocean circulation. Because carbon transfer relates to carbon fluxes, while carbon pumps relate to carbon stocks, the strength of the different carbon transfers is also complementary but not equivalent to the strength of the carbon pumps. For instance, a change in carbon obduction could affect the strength of the biological pump even without any change in sedimentation because carbon and limiting nutrients are not necessarily coupled.

\subsection{What are the Main Uncertainties of our Approach?}

[34] The main uncertainty in our results concerns the evaluation of the ventilation rate for a series of reasons. First, as noted before, the rate of ventilation estimated in our model and data is biased toward contemporary ocean values. This implies that the carbon transfers that we have estimated are not strictly representative of the preindustrial period, although there is no anthropogenic carbon in our model ocean, nor in our corrected DIC climatology. Second, there is a large uncertainty regarding the role of eddy mixing. We accounted for this term very crudely, using the GM scheme of our coarse resolution model. Different ocean circulation models, using different resolutions and eddy closures, support different rates of ventilation [Gnanadesikan et al., 2004], which in turn would produce different estimates of carbon subduction. Eddy-resolving models [Paci et al., 2007; Karleskind et al., 2011a; Lee and Nurser, 2012] show that eddies can affect subduction rates in a variety of ways, which are not yet fully understood.

[35] Finally, subduction is generally defined as that part of detrained fluid that is not reentrained in the mixed layer within the same seasonal cycle. By integrating over the year the carbon fluxes across the instantaneous mixed layer (thus following Valdivieso Da Costa et al. [2005] and Karleskind et al. [2011b]), we measure the net annual mean of seasonally varying fluxes which are generally strongly dominated by detrainment and entrainment at the seasonal and intraseasonal time scales. This method is an approximation as the definition of subduction applies in a Lagrangian framework [Qiu and Huang, 1995] and is computed here in an Eulerian framework. A common assumption to overcome this issue is to compute subduction from time-averaged annual velocities and across the base of the winter mixed-layer $h_{\max }$ and over an effective subduction period of the order of 1 to 2 months [Marshall et al., 1993; Marshall and Marshall, 1995; Hazeleger and Drijfhout, 2000]. However, this simplification is not suited to diagnose carbon subduction because of the strong seasonality of the carbon content in the mixed layer due to biological activity.

\subsection{How Does Carbon Penetrate Into the Ocean Interior?}

[36] With these uncertainties in mind, our diagnostics permit us to estimate how much of the carbon flux to the deep ocean is due to physical processes and how much is due to biological processes. While biological activity is key to carbon export to depth through sinking of organic particles, our results emphasize that carbon subduction is the main communication route between the surface of the ocean and the interior. We have highlighted that subduction does not occur uniformly over the globe but in specific regions which are shown in Figure 4a. At temperate latitudes, our results suggest that $\sim 90 \%$ of the carbon penetration actually ensues from subduction. This generalizes the findings of Karleskind et al. [2011b] for the Northeast Atlantic, of Oschlies and Kähler [2004] for the Northwest Atlantic, and of Ayers and Lozier [2012] for the North Pacific transition zone region. Moreover, we found that subduction of organic matter from the surface ocean represents $\sim 30 \%$ of the total organic matter flux in these same regions. It should be noted that this form of export is achieved mainly through particulate fraction in our model (Table S1). It is very likely that our estimate of DOC subduction is strongly underestimated, because the biogeochemical model (PISCES) only accounts for the labile and semilabile fraction of DOC [Aumont and Bopp, 2006], which constitutes a small fraction of total DOC [Hansell et al., 2012]. Carlson et al. [1994] estimate that DOC export represents about $20 \%$ of the total organic carbon export. Our result thus probably represents a lower bound.

\section{Conclusions}

[37] Carbon transfers across the mixed-layer interface due to physical processes, i.e., carbon subduction and carbon obduction, are key components of the surface ocean carbon budget. The export of organic carbon by subduction is nearly equal to the export by sedimentation of organic particles at temperate and high latitudes. Physical transfers of DIC are one order larger in magnitude than export of organic material and than air-sea fluxes; at temperate latitudes, DIC subduction dominates over sinking of particles in maintaining the waters undersaturated. In the tropical band and in the Southern Ocean, DIC is obducted back to the surface.

[38] In our analysis, the contribution of eddy fluxes to the carbon transfers appear to be small when compared to the that of the mean advection terms. However, there is a large uncertainty associated with this term and there is still a long way to go in understanding its quantitative contribution.

[39] Ocean ventilation, and the related exchanges of carbon between the ocean surface and interior, did not remain constant in the past and will likely change in the future. In this context of a varying ocean, our results emphasize that without constraints on changes in circulation and physical carbon transfers, changes in export production or surface nutrients will not be sufficient to explain changes in the total oceanic storage of carbon and in atmospheric $\mathrm{pCO}_{2}$. Our transfer diagnostics can be easily applied to a system which is out of equilibrium and should permit to gain insight on how variability of the ocean circulation impacts carbon fluxes in the ocean.

[40] Finally, one outcome of this study was the identification of the main regions where carbon is subducted into the interior of the ocean. However, for effective sequestration, the subducted carbon must be transported into the ocean interior away from obduction regions [Krémeur et al., 2009; 
Sallée et al., 2012]. The fate of this carbon once in the deeper ocean remains a topic for future study; it may be temporarily sequestered in mode waters, or it may be carried to tropical regions or to the Southern Ocean or to north latitude subpolar gyres where it will be delivered back to the surface. Thus, an important question which remains to be addressed is the time scale over which the carbon remains in the interior and how this time scale may be modified by interannual variability in the physical carbon transfers.

[41] Acknowledgments. Horizontal velocities produced by Ssalto/ Duacs and distributed by AVISO, with support from CNES were used. The model simulations were performed at IDRIS (France). This work was supported through CNRS (INSU-LEFE TANGGO project), TOSCA-CNES (CPUMP project), EU FP7 project CARBOCHANGE (Changes in carbon uptake and emissions by oceans in a changing climate) which received funding from the European Community's Seventh Framework Programme under grant agreement 264879 and from the EU FP7 Marie Curie International Research Staff Exchange Scheme (IRSES) Fellowship SOCCLI (The role of Southern Ocean Carbon cycle under CLImate change), which received funding from the European Commission's Seventh Framework Programme under grant agreement 317699. We thank two anonymous reviewers and Pedro S. Monteiro for their comments which helped to improve the initial manuscript.

\section{References}

Aumont, O., and L. Bopp (2006), Globalizing results from ocean in situ iron fertilization studies, Global Biogeochem. Cycles, 20, GB2017, doi:10.1029/2005GB002591.

Ayers, J. M., and M. S. Lozier (2012), Unraveling dynamical controls on the north pacific carbon sink, J. Geophys. Res., 117(C1), C01017, doi: $10.1029 / 2011 \mathrm{JC} 007368$.

Bates, N. R., A. C. Pequignet, R. J. Johnson, and N. Gruber (2002), A shortterm sink for atmospheric $\mathrm{CO}_{2}$ in subtropical mode water of the north atlantic ocean, Nature, 420, 489-493.

Cao, L., M. Eby, A. Ridgwell, K. Caldeira, D. Archer, A. Ishida, F. Joos, K. Matsumoto, U. Mikolajewicz, and A. Mouchet (2009), The role of ocean transport in the uptake of anthropogenic $\mathrm{CO}_{2}$, Biogeosciences, 6 , 375-390.

Carlson, C. A., H. W. Ducklow, and A. F. Michaels (1994), Annual flux of dissolved organic carbon from the euphotic zone in the northwestern Sargasso Sea, Nature, 371, 405-408.

Cushman-Roisin, B. (1987), Subduction, in Dynamics of the Oceanic Surface Mixed Layer, Proceedings, Hawaiian Winter Workshop, pp. 181-196, Univ. of Hawaii at Manoa, Manoa, Hawaii.

de Boyer Montégut, C., G. Madec, A. Fischer, A. Lazar, and D. Iudicone (2004), Mixed layer depth over the global ocean: An examination of profile data and a profile-based climatology, J. Geophys. Res., 109, C12003, doi:10.1029/2004JC002378

de Miranda, A. P., B. Barnier, and W. K. Dewar (1999), Mode waters and subduction rates in a high-resolution South Atlantic simulation, 57, 213-244.

Denman, K. L., et al. (2007), Couplings between changes in the climate system and biogeochemistry, in Climate Change 2007: The Physical Science Basis Contribution of Working Group I to the Fourth Assessment Report of the Intergovernmental Panel on Climate Change (AR4), edited by S. Solomon et al., pp. 500-587, Cambridge Univ. Press, Cambridge, U. K., and New York.

Devries, T., F. Primeau, and C. Deutsch (2012), The sequestration efficiency of the biological pump, Geophys. Res. Lett., 39, L13601, doi:10.1029/2012GL051963.

Dunne, J., R. Armstrong, A. Gnanadesikan, J. Sarmiento, and R. Slater (2005), Empirical and mechanistic models for the particle export ratio, Global Biogeochem. Cycles, 19, GB4026, doi:10.1029/2004GB002390.

Follows, M. J., R. G. Williams, and J. C. Marshall (1996), The solubility pump of carbon in the subtropical gyre of the North Atlantic, J. Mar. Res., $54,605-630$.

Gent, P. R., and J. C. McWilliams (1990), Isopycnal mixing in ocean circulation models, J. Phys. Oceanogr., 20, 150-155.

Gnanadesikan, A., J. Dunne, R. Key, K. Matsumoto, J. Sarmiento, R. Slater, and P. Swathi (2004), Oceanic ventilation and biogeochemical cycling: Understanding the physical mechanisms that produce realistic distributions of tracers and productivity, Global Biogeochem. Cycles, 18 GB4010, doi:10.1029/2003GB002097.
Gruber, N., et al. (2009), Oceanic sources, sinks, and transport of atmospheric $\mathrm{CO}_{2}$, Global Biogeochem. Cycles, 23, GB1005, doi:10.1029/ 2008 GB003349.

Hansell, D. A., C. A. Carlson, and R. Schlitzer (2012), Net removal of major marine dissolved organic carbon fractions in the subsurface ocean, Global Biogeochem. Cycles, 26, GB1016, doi:10.1029/2011GB004069.

Hazeleger, W., and S. Drijfhout (2000), Eddy subduction in a model of the subtropical gyre, J. Phys. Oceanogr., 30, 677-695.

Ito, T., and M. J. Follows (2005), Preformed phosphate, soft tissue pump and atmospheric $\mathrm{CO}_{2}$, J. Mar. Res., 63, 813-839.

Iudicone, D., K. B. Rodgers, I. Stendardo, and O. Aumont (2011), Water masses as a unifying framework for understanding the Southern Ocean carbon cycle, Biogeosciences, 8, 1031-1052.

Karleskind, P., M. Lévy, and L. Memery (2011a), Modifications of mode water properties by sub-mesoscales in a bio-physical model of the northeast Atlantic, Ocean Model., 39, 47-60.

Karleskind, P., M. Lévy, and L. Memery (2011b), Subduction of carbon, nitrogen, and oxygen in the northeast Atlantic, J. Geophys. Res., 116, C02025, doi:10.1029/2010JC006446.

Key, R. M. (2004), A global ocean carbon climatology: Results from GLobal Data Analysis Project (GLODAP), Global Biogeochem. Cycles, 18, GB4031, doi:10.1029/2004GB002247.

Krémeur, A., M. Lévy, O. Aumont, and G. Reverdin (2009), Impact of the subtropical mode water biogeochemical properties on primary production in the North Atlantic: New insights from an idealized model study, J. Geophys. Res., 114, C07019, doi:10.1029/2008JC005161.

Large, W. G., and S. G. Yeager (2008), The global climatology of an interannually varying air-sea flux data set, Clim. Dyn., 33, 341-364.

Laws, E. A., P. G. Falkowski, W. O. Smith, H. Ducklow, and J. J. McCarthy (2000), Temperature effects on export production in the open ocean, Global Biogeochem. Cycles, 14, 1231-1246.

Le Quere, C., T. Takahashi, and E. T. Buitenhuis (2010), Impact of climate change and variability on the global oceanic sink of $\mathrm{CO}_{2}$, Global Biogeochem. Cycles, 24, GB4007, doi:10.1029/2009GB003599.

Lee, M. M., and A. J. G. Nurser (2012), Eddy subduction and the vertical transport streamfunction, J. Phys. Oceanogr., 42, 1762-1780.

Lee, M. M., A. J. G. Nurser, I. Stevens, and J. B. Sallée (2011), Subduction over the Southern Indian Ocean in a high-resolution atmosphere-ocean coupled model, J. Clim., 24, 3830-3849.

LeQuere, C., et al. (2007), Saturation of the Southern Ocean $\mathrm{CO}_{2}$ sink due to recent climate change, Science, 316, 1735-1738.

Levine, N. M., S. C. Doney, I. Lima, R. Wanninkhof, N. R. Bates, and R. A. Feely (2011), The impact of the North Atlantic Oscillation on the uptake and accumulation of anthropogenic $\mathrm{CO}_{2}$ by North Atlantic Ocean mode waters, Global Biogeochem. Cycles, 25, GB3022, doi:10.1029/2010GB003892.

Lévy, M. (2005), Nutrients in remote mode, Nature, 437, 29.

Madec, G. (2008), NEMO Ocean Engine, Note du Pole de modelisation de 1'Institut Pierre-Simon Laplace (IPSL), France.

Madec, G., and M. Imbard (1996), A global ocean mesh to overcome the North Pole singularity, Clim. Dyn., 12, 381-388.

Mahadevan, A., A. Tagliabue, L. Bopp, A. Lenton, L. Memery, and M. Levy (2011), Impact of episodic vertical fluxes on sea surface $\mathrm{pCO}_{2}$, Philos. Trans. R. Soc. London, Ser. A, 369, 2009-2025.

Marinov, I., M. Follows, A. Gnanadesikan, J. L. Sarmiento, and R. D. Slater (2008a), How does ocean biology affect atmospheric $\mathrm{pCO}_{2}$ ? Theory and models, J. Geophys. Res., 113, C07032, doi:10.1029/ 2007JC004598.

Marinov, I., A. Gnanadesikan, J. L. Sarmiento, J. R. Toggweiler, M. Follows, and B. K. Mignone $(2008 \mathrm{~b})$, Impact of oceanic circulation on biological carbon storage in the ocean and atmospheric $\mathrm{pCO}_{2}$, Global Biogeochem. Cycles, 22, GB3007, doi:10.1029/ $2007 \mathrm{~GB} 002958$.

Marshall, D., and J. Marshall (1995), On the thermodynamics of subduction, J. Phys. Oceanogr., 25, 138-151.

Marshall, J., A. Nurser, and R. Williams (1993), Inferring the subduction rate and period over the North Atlantic, J. Phys. Oceanogr., 23, $1315-1329$.

Mikaloff Fletcher, S. E., et al. (2007), Inverse estimates of the oceanic sources and sinks of natural $\mathrm{CO}_{2}$ and the implied oceanic carbon transport, Global Biogeochem. Cycles, 21, GB1010, doi:10.1029/ 2006GB002751.

Oschlies, A., and P. Kähler (2004), Biotic contribution to air-sea fluxes of $\mathrm{CO}_{2}$ and $\mathrm{O}_{2}$ and its relation to new production, export production, and net community production, Global Biogeochem. Cycles, 18, GB1015, doi:10.1029/2003GB002094.

Paci, A., G. Caniaux, H. Giordani, M. Lévy, L. Prieur, and G. Reverdin (2007), A high-resolution simulation of the ocean during the POMME experiment: Mesoscale variability and near surface processes, $J$. Geophys. Res., 112, C04007, doi:10.1029/2005JC003389. 


\section{LEVY ET AL.: PHYSICAL CARBON FLUXES}

Palter, J., M. Lozier, and R. Barber (2005), The effect of advection on the nutrient reservoir in the North Atlantic subtropical gyre, Nature, 437, 687-692.

Palter, J. B., and M. S. Lozier (2008), On the source of Gulf Stream nutrients, J. Geophys. Res., 113, C06018, doi:10.1029/2007JC004611.

Prentice, C. I., et al. (2001), The carbon cycle and atmospheric $\mathrm{CO}_{2}$, in Climate Change: The Scientific Basis, The Contribution Of WGI Of The IPCC to the IPCC Third Assessment Report (TAR), edited by J. T. Houghton and D. Yihui, pp. 183-237, Cambridge Univ. Press, Cambridge, U. K.

Qiu, B., and R. X. Huang (1995), Ventilation of the North Atlantic and North Pacific: Subduction versus obduction, J. Phys. Oceanogr., 25, 2374-2388

Qu, T., S. Gao, I. Fukumori, R. A. Fine, and E. J. Lindstrom (2010), The obduction of Equatorial $13^{\circ} \mathrm{C}$ Water in the Pacific identified by a simulated passive tracer, J. Phys. Oceanogr., 40, 2282-2297.

Riebesell, U., A. Körtzinger, and A. Oschlies (2009), Sensitivities of marine carbon fluxes to ocean change, PNAS, 106, 20,602.

Sallée, J. B., R. J. Matear, S. R. Rintoul, and A. Lenton (2012), Localized subduction of anthropogenic carbon dioxide in the Southern Hemisphere oceans, Nat. Geosci., 5, 579-584.

Sallée, J. B., K. Speer, S. Rintoul, and S. Wijffels (2010), Southern Ocean thermocline ventilation, J. Phys. Oceanogr., 40, 509-529.

Sarmiento, J. L., and N. Gruber (2006), Ocean Biogeochemical Dynamics, Princeton Univ. Press, Princeton, N. J.

Schlitzer, R. (2002), Carbon export fluxes in the Southern Ocean: Results from inverse modeling and comparison with satellite-based estimates, Deep Sea Res., Part II, 49, 1623-1644.

Schlitzer, R. (2004), Export production in the Equatorial and North Pacific derived from dissolved oxygen, nutrient and carbon data, J. Oceanogr., $60,53-62$.

Thomas, H., A. E. Friederike Prowe, I. D. Lima, S. C. Doney, R. Wanninkhof, R. J. Greatbatch, U. Schuster, and A. Corbière (2008), Changes in the North Atlantic Oscillation influence $\mathrm{CO}_{2}$ uptake in the North Atlantic over the past 2 decades, Global Biogeochem. Cycles, 22, GB4027, doi:10.1029/2007GB003167.
Timmermann, R., H. Goosse, G. Madec, T. Fichefet, C. Ethe, and V. Duliere (2005), On the representation of high latitude processes in the ORCA-LIM global coupled sea ice-ocean model, Ocean Model., 8 , 175-201.

Trossman, D. S., L. Thompson, S. Mecking, and M. J. Warner (2012), On the formation, ventilation, and erosion of mode waters in the North Atlantic and Southern Oceans, J. Geophys. Res., 117, C09026, doi:10.1029/2012JC008090.

Ullman, D. J., G. A. Mckinley, V. Bennington, and S. Dutkiewicz (2009), Trends in the North Atlantic carbon sink: 1992-2006, Global Biogeochem. Cycles, 23, GB4011, doi:10.1029/2008GB003383.

Valdivieso Da Costa, M., H. Mercier, and A. Treguier (2005), Effects of the mixed layer time variability on kinematic subduction rate diagnostics, $J$. Phys. Oceanogr., 35, 427-443.

Volk, T., and M. Hoffert (1985), Ocean carbon pumps: Analysis of relative strengths and efficiencies in ocean-driven atmospheric $\mathrm{CO}_{2}$ changes, in The Carbon Cycle and Atmospheric $\mathrm{CO}_{2}$ : Natural Variations Archean to Present, Geophys. Monogr. Ser., vol. 32, edited by E. T. Sundquist and W. S. Broecker, pp. 99-110, AGU, Washington, D. C.

Wanninkhof, R. (1992), Relationship between wind speed and gas exchange over the ocean, J. Geophys. Res., 97, 7373-7382.

Williams, R., V. Roussenov, and M. Follows (2006), Nutrient streams and their induction into the mixed layer, Global Biogeochem. Cycles, 20, GB1016, doi:10.1029/2005GB002586.

Williams, R. G., and M. J. Follows (2011), Ocean Dynamics and the Carbon Cycle, Cambridge Univ. Press, Cambridge, U. K.

Williams, R. G., E. McDonagh, V. M. Roussenov, S. Torres-Valdes, B. King, R. Sanders, and D. A. Hansell (2011), Nutrient streams in the North Atlantic: Advective pathways of inorganic and dissolved organic nutrients, Global Biogeochem. Cycles, 25, GB4008, doi:10.1029/2010GB003853.

Wu, L., Z. Jing, S. Riser, and M. Visbeck (2011), Seasonal and spatial variations of Southern Ocean diapycnal mixing from Argo profiling floats, Nat. Geosci., 4, 363-366. 